\title{
Faktor-Faktor yang Mempengaruhi Perilaku Remaja ke Posyandu di Wilayah Kerja Puskesmas Muara Bulian
}

\author{
Yunia Lisma ${ }^{1}$, Ruwayda ${ }^{2}$ \\ 1,2 Jurusan Poltekkes Kemenkes Jambi \\ Email:lismayunia5@gmail.com
}

Submitted : 05/02/2021

Accepted: 10/09/2021

Published: 15/09/2021

\begin{abstract}
Posyandu is expected to be a place to facilitate youth in understanding adolescent health problems, find alternative solutions to problems, form youth support groups, expand the reach of PKPR Puskesmas, especially for regional youth who have limited access Data shows that Muara Bulian Health Center, one of the Puskesmas in Batang Hari has provided health services to adolescents through PKPR activities. In 2018 the teen pregnancy rate was 24 teenagers (1.4\%), in 2019 there were 27 teenagers (1.6\%) An increase of 0.2\%. In December 2019, two pilots polyandrous were formed in the work area of the Muara Bulian Community Health Center.This research is a descriptive analytic study with cross sectional method. The population in this study were adolescents who came to Posyandu cendana and singkawang which amounted to 75 people, while the number of samples is 43 people. This research uses purposive sampling technique. Data collection is done by questionnaire. The analysis was carried out univariately and bivariately. Results of the study Some respondents had bad behavior (51.2\%) visited Posyandu Most respondents had poor knowledge (55.8\%), positive attitude (51.2\%), and good family support (62.8\%), a good source of information (58.1\%), most cadres had a good role (53.5\%) in providing services in the Posyandu area of Muara Bulian Puskesmas in 2020. There is a meaningful relationship between knowledge and adolescent behavior. There is a significant relationship between attitude and adolescent behavior. There is a significant relationship between distance with adolescent behavior, there is a significant relationship between information sources and adolescent behavior, there is a relationship between the role of officers with adolescent behavior, and there is a significant relationship between family support and adolescent behavior to the Posyandu in the Public Health Service Muara Bulian Work Area
\end{abstract}

Keywords: adolenscence behaviour to posyandu, attitude, distance, information source, role of officer,family support,

Abstrak
Posyandu Remaja diharapkan dapat menjadi wadah untuk memfasilitasi remaja dalam memahami permasalahan kesehatan remaja,menemukan alternatif pemecahan masalah, membentuk kelompok dukungan remaja, memperluas jangkauan Puskesmas PKPR, terutama bagi remaja daerah yang memiliki keterbatasan akses. Data menunjukkan Puskesmas Muara Bulian salah satu Puskesmas di Batang hari telah memberikan pelayanan kesehatan kepada remaja melalui kegiatan PKPR. Tahun 2018 angka kehamilan pada remaja berjumlah 24 remaja (1,4\%), tahun 2019 berjumlah 27 remaja $(1,6 \%)$ Terjadi peningkatan 0,2\%. Pada bulan Desember 2019 telah dibentuk percontohan dua posyandu remaja di wilayah kerja Puskesmas Muara Bulian. Penelitian ini merupakan penelitian deskriftif analitik dengan metode cross sectional. Populasi pada penelitian ini adalah remaja yang datang ke Posyandu cendana dan singkawang yaitu berjumlah 75 orang, sedangkan untuk jumlah sampel yaitu sebanyak 43 orang. Penelitian ini menggunakan tehnik Purposive sampling. Pengumpulan data dilakukan dengan kuesioner. Analisis dilakukan secara univariat danbivariat . Hasil penelitian Sebagian responden memiliki perilaku kurang baik $(51,2 \%)$ berkunjung ke posyandu Sebagian besar responden memiliki pengetahuan kurang baik(55,8\%), sikap positif(51,2\%), dan dukungan keluarga baik $(62,8 \%)$, sumber informasi baik $(58,1 \%)$,sebagian besar kader sudah berperan dengan baik $(53,5 \%)$ dalam memberikan pelayanan di posyandu wilayah kerja puskesmas muara bulian Tahun 2020. Ada hubungan yang bermakna antara pengetahuan dengan perilaku remaja. Ada hubungan yang bermakna antara sikap dengan perilaku remaja. Ada hubungan yang bermakna antara jarak dengan perilaku remaja, ada hubungan yang 
bermakna antara sumber informasi dengan perilaku remaja, ada hubungan antara peran petugas dengan perilaku remaja, dan ada hubungan yang bermakna antara dukungan keluarga dengan perilaku remaja ke posyandu di Wilayah Kerja Puskesmas Muara Bulian.

Kata Kunci: dukungan keluarga, jarak, pengetahuan, peran petugas, posyandu remaja, sikap,sumber informasi

\section{PENDAHULUAN}

Posyandu remaja merupakan salah satu bentuk Upaya Kesehatan Bersumber Daya Masyarakat (UKBM)yang dikelola dan diselenggarakan dari, oleh, untuk dan bersama seluruh masyarakat termasuk remaja dalam memberdayakan masyarakat dan memberikan kemudahan dalam memperoleh pelayanan kesehatan bagi remaja untuk meningkatkan derajat kesehatan dan keterampilan hidup sehat remaja (Kemenkes RI, 2018:14).

Tujuan dari kegiatan posyandu remaja yaitu mendekatkan akses dan meningkatkan cakupan layanan kesehatan bagi remaja, sedangkan fungsi posyandu remaja salah satunya sebagai wadah pemberdayaan masyarakat dalam alih informasi dan keterampilan untuk meningkatkan derajat kesehatan dan keterampilan hidup sehat remaja (Kemenkes RI, 2018:16).

Posyandu remaja yang terdata di Provinsi Jambi berjumlah 15 posyandu yang terlaporkan (Dinkes Provinsi Jambi, 2019). Posyandu remaja di Kabupaten Batang hari berjumlah 7 posyandu (Dinkes Batanghari, 2019). Sementara berdasarkan Petunjuk teknis penyelenggaraan posyandu remaja Kementerian Kesehatan 2018 selayaknya posyandu remaja berada disetiap desa/kelurahan dan beranggotakan maksimal 50 orang remaja (Kemenkes RI, 2018:19).

Puskesmas Muara Bulian salah satu Puskesmas di Kabupaten Batang Hari telah memberikan pelayanan kesehatan kepada remaja melalui kegiatan PKPR. Berdasarkan hasil laporan kesehatan remaja pada tahun 2018 angka kehamilan remaja diwilayah Puskesmas Muara Bulian berjumlah 24 remaja (1,4\%), tahun 2019 berjumlah 27 remaja $(1,6 \%)$, terjadi peningkatan $0,2 \%$. Pada bulan Desember
2019 telah dibentuk percontohan dua posyandu remaja di wilayah kerja Puskesmas Muara Bulian yang diharapkan dapat menjadi wadah untuk memfasilitasi permasalahan kesehatan remaja, terutama bagi remaja yang memiliki keterbatasan akses.

Penyataan ini didukung oleh penelitian Mia apritia,M. Zen Rahfiludin dan Dharmintotentang peran posyandu remaja terhadap perilaku kesehatan reproduksi remaja menunjukan bahwa terdapat perbedaan yang bermakna mengenai pengetahuan tentang kesehatan reproduksi antara remaja yang mengikuti posyandu dan yang tidak mengikuti posyandu. Hasil penelitian Indah tentang faktor-faktor yang berhubungan dengan perilaku ibu balita dalam menimbang anaknya ke posyandu yaitu tidak terdapat hubungan antara jarak keposyandu dengan perilaku kunjungan ke posyandu dan hasil penelitian Darmawan yaitu adanya hubungan antara dukungan keluarga dengan pemanfaatan pelayanan posyandu.

Dengan adanya posyandu remaja percontohan yang baru terbentuk di wilayah kerja Puskesmas Muara Bulian sehingga peneliti tertarik untuk mengetahui faktor-faktor yang mempengaruhi perilaku remaja ke posyandu di Puskesmas Muara Bulian tahun 2020.

\section{METODEPENELITIAN}

Desain Penelitian ini menggunakan rancangan deskriptif analitik dengan pendekatan cross sectional, dimana variabel independen dan dependen dilakukan pengukuran sekaligus secara bersamaan(Arikunto,2012).Penelitian ini dilakukan di Posyandu Singkawang dan Cendana di kelurahan Teratai. Penelitian ini dilaksanakan pada bulan Januari - Juni 2020. Populasi dalam penelitian ini adalah 
remaja yang datang ke posyandu diwilayah kerja Puskesmas Muara Bulian yaitu Posyandu Singkawang berjumlah 35 responden dan Posyandu Cendana berjumlah 40 responden, jadi dengan total keseluruhan sebanyak 75 responden. Penelitian bersumber dari dataprimer yang diperoleh melalui pengisian kuesioner secara langsung mengenai pengetahuan, sikap, jarak posyandu, sumber informasi, peran petugas dan dukungan keluarga terhadapperilaku remaja ke Posyandudi wilayah kerja puskesmas Muara Bulian Tahun 2020. Kualitasdata tergantung dari kejujuran para responden dalam mengisi kuesioner. Kelemahan dari kuesioner Peneliti tidak dapat melihat reaksi responden ketika memberikan informasi melalui isian kuesioner tanggapan dan jawaban responden asal-asalan. Sampel dalam penelitian ini adalah 43 responden dengan menggunakan Purposive sampling. Dalam pelaksanaannya peneliti dibantu oleh 2orangkader kesehatan.Analisis dari penelitian ini dilakukan secara univariat, untuk melihat distribusi frekuensi masing-masing variabel yaitu perilaku, pengetahuan, sikap, jarak posyandu, sumber informasi, peran petugas dan dukungan keluarga.dananalisa bivariatuntukmelihat apakahadahubungan bermakna antaravariabel dependen dan independen

\begin{tabular}{lcc}
\multicolumn{3}{l}{ HASIL DAN PEMBAHASAN } \\
$\begin{array}{l}\text { Tabel 1.Distribusi } \\
\text { Berdasarkan } \\
\text { kePosyandu }\end{array}$ & $\begin{array}{r}\text { perilaku } \\
\text { di Wesponden } \\
\text { Puskesmas Muara Bulian }\end{array}$ & $\begin{array}{r}\text { remaja } \\
\text { Kerja }\end{array}$ \\
$\begin{array}{l}\text { Tingkat } \\
\text { Perilaku Remaja }\end{array}$ & $\mathrm{f}$ & $\%$ \\
\hline Baik & 21 & 48,8 \\
Kurang Baik & 22 & 52,2 \\
Jumlah & 43 & 100 \\
\hline
\end{tabular}

Mayoritas responden yang memiliki perilaku kurang baik yaitu sebanyak 22 responden $(52,2 \%)$ dan perilaku baik yaitu sebanyak 21 responden (48,8\%). Hasil pengukuran ini berdasarkan jumlah kunjungan yang dilakukan oleh remaja dari bulan Januari 2020 s/d Maret 2020.

Tabel 2. Distribusi Hubungan Pengetahuan terhadap Perilaku Remaja kePosyandudi Wilayah KerjaPuskesmas Muara Bulian

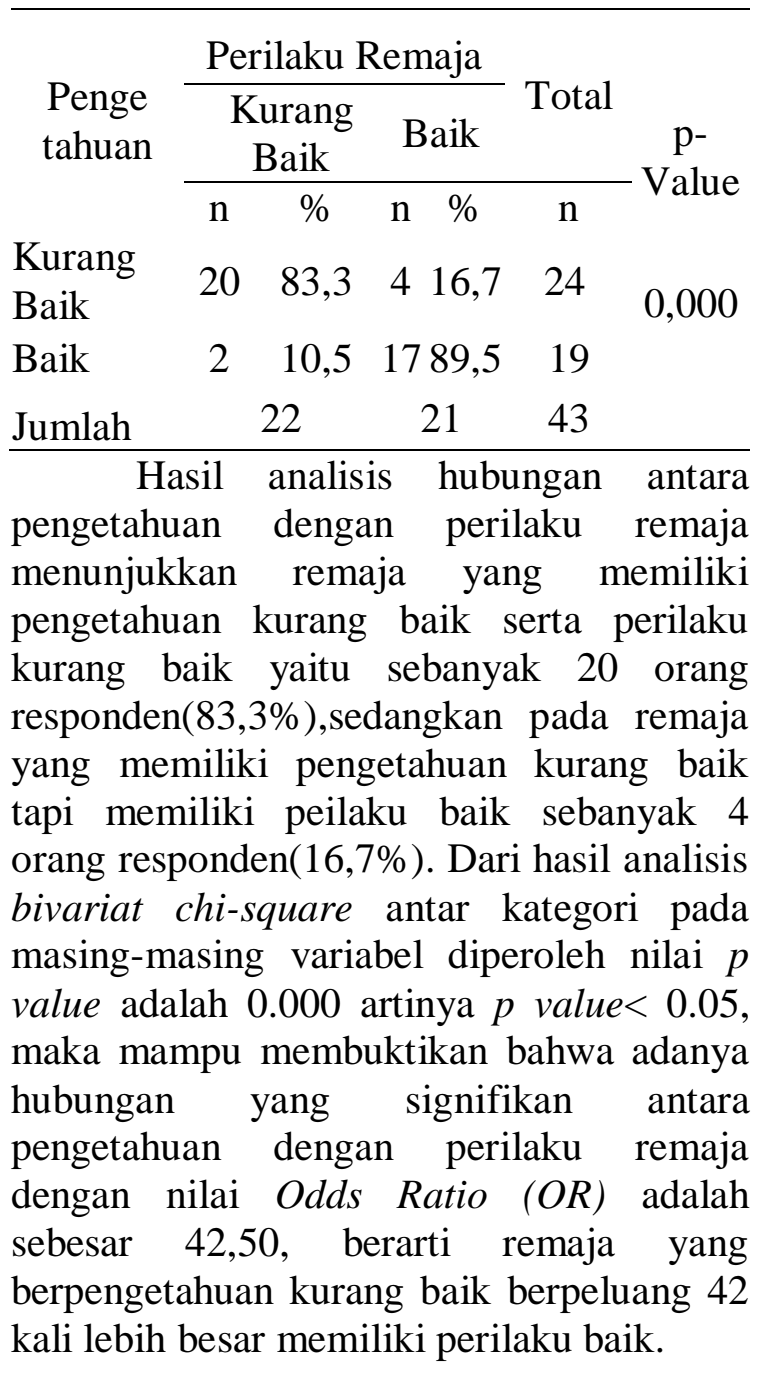

Tabel 3. Distribusi Hubungan Sikap terhadap Perilaku Remaja ke Posyandu di Wilayah Kerja Puskesmas Muara Bulian 


\begin{tabular}{|c|c|c|c|c|c|}
\hline \multirow{3}{*}{ Sikap } & \multicolumn{3}{|c|}{ Perilaku Remaja } & \multirow{2}{*}{\multicolumn{2}{|c|}{ Totalp-Value }} \\
\hline & \multicolumn{2}{|c|}{ Kurang Baik } & Baik & & \\
\hline & $\mathrm{n}$ & $\%$ & $\mathrm{n} \quad \%$ & $\mathrm{n}$ & \\
\hline Negatif & 20 & 90,9 & 14,8 & 21 & 0.001 \\
\hline Positif & 2 & 9,1 & 2095,2 & 22 & \\
\hline Jumlah & & 22 & 21 & 43 & \\
\hline
\end{tabular}

Hasil analisis hubungan antara sikap dengan perilaku remaja menunjukkan remaja yang memiliki sikap positif serta perilaku baik yaitu sebanyak 20 orang responden $(90,9 \%)$, sedangkan pada remaja yang memiliki sikap positif dan memiliki perilaku kurang baik sebanyak 2 orang responden $(9,1 \%)$. Dari hasil analisis bivariat chi-square antar kategori pada masing-masing variabel diperoleh nilai $p$ value adalah 0.001 artinya $p$ value $<0.05$, maka mampu membuktikan bahwa adanya hubungan yang signifikan antara sikap dengan perilaku remaja dengan nilai Odds Ratio (OR) adalah sebesar 20,00 berarti remaja yang memiliki sikap negatif berpeluang perilaku baik sebanyak 20 kali lebih besar untuk ke posyandu dibandingkan dengan remaja yang memiliki sikap positif.

\section{Tabel 4. Distribusi Hubungan Jarak Posyandu terhadap Perilaku Remaja ke Posyandu di Wilayah Kerja Puskesmas ke Posyandudi Wilayah Kerja Puskesmas}

\begin{tabular}{|c|c|c|c|c|c|c|}
\hline \multirow{3}{*}{$\begin{array}{l}\text { Jarak } \\
\text { Posy } \\
\text { andu }\end{array}$} & \multicolumn{4}{|c|}{ Perilaku Remaja } & \multirow{3}{*}{ Total } & \multirow{3}{*}{ p-Value } \\
\hline & \multicolumn{2}{|c|}{$\begin{array}{c}\text { Kurang } \\
\text { Baik }\end{array}$} & \multicolumn{2}{|c|}{ Baik } & & \\
\hline & $\mathrm{n}$ & $\%$ & $\mathrm{n}$ & $\%$ & & \\
\hline$<1 \mathrm{~km}$ & 21 & 72,4 & 8 & 27,6 & 29 & \\
\hline$>1 \mathrm{~km}$ & 1 & 7,1 & 13 & 92,9 & 14 & 0.000 \\
\hline Jumlah & & 22 & & 21 & 43 & \\
\hline
\end{tabular}

Hasil analisis hubungan antara jarak posyandu dengan perilaku remaja menunjukkan remaja yang menempuh jarak $<1 \mathrm{~km}$ dan perilaku kurang baik yaitu sebanyak 21 orang responden $(72,4 \%)$, sedangkan pada remaja menempuh jarak $>1$ $\mathrm{km}$ dan memiliki perilaku baik sebanyak 8 orang responden(27,6\%). Dari hasil analisis bivariat chi-square antar kategori pada masing-masing variabel diperoleh nilai $p$ value adalah 0.000 artinya $p$ value $<0.05$, maka mampu membuktikan bahwa adanya hubungan yang signifikan antara jarak posyandu dengan perilaku remaja dengan nilai Odds Ratio (OR) adalah sebesar 34,125, berarti remaja yang menempuhperjalanan dengan jarakposyandu $>1 \mathrm{kmberpeluang}$ perilaku bai k sebanyak34 kali lebih besar untuk ke pusk esmas dibandingkan dengan remaja yang $\mathrm{m}$ enempuh jarak posyandu $<1 \mathrm{~km}$.

Tabel 5. Distribusi Hubungan Sumber Informasi terhadap Perilaku Remaja ke Posyandu di Wilayah Kerja Puskesmas

\begin{tabular}{|c|c|c|c|c|c|}
\hline \multirow{3}{*}{$\begin{array}{l}\text { Sumber } \\
\text { Informasi }\end{array}$} & \multicolumn{3}{|c|}{ Perilaku Remaja } & \multirow{2}{*}{ Total } & \multirow{3}{*}{$\begin{array}{c}\mathrm{p}- \\
\text { Value }\end{array}$} \\
\hline & $\begin{array}{c}\text { Kurang } \\
\text { Baik }\end{array}$ & \multicolumn{2}{|c|}{ Baik } & & \\
\hline & $\%$ & $\mathrm{n}$ & $\%$ & $\mathrm{n}$ & \\
\hline Tidak & 1583,3 & 3 & 16,7 & 1 & \\
\hline Ya & 728,0 & 18 & 72,0 & 2 & 0.001 \\
\hline Jumlah & 22 & 21 & & 43 & \\
\hline
\end{tabular}
Hasil analisis hubungan antara sumber informasi dengan perilaku remaja menunjukkan remaja yang mendapatkan sumber informasi serta perilaku baik yaitu sebanyak 18 orang responden (72\%), sedangkan pada remaja yang mendapatkan sumber informasi dan memiliki perilaku kurang baik sebanyak 7 orang responden (28\%). Dari hasil analisis bivariat chisquare antar kategori pada masing-masing variabel diperoleh nilai $p$ value adalah 0.001 artinya $p$ value $<0.05$, maka mampu membuktikan bahwa adanya hubungan yang signifikan antara sumber informasi dengan perilaku remaja dengan nilai $O d d s$ Ratio (OR) adalah sebesar 12,857 berarti 
remaja yang tidak mendapatkan sumber informasi berpeluang perilaku baik sebanyak 12 kali lebih besar untuk ke puskesmas dibandingkan dengan remaja yang mendapatkan sumber informasi.

\section{Tabel 6. Distribusi Hubungan Peran Petugas terhadap Perilaku Remaja ke Posyandu di Wilayah Kerja Puskesmas Muara Bulian}

\begin{tabular}{|c|c|c|c|c|c|c|}
\hline \multirow{3}{*}{$\begin{array}{l}\text { Peran } \\
\text { Petugas }\end{array}$} & \multicolumn{4}{|c|}{ Perilaku Remaja } & \multirow[b]{2}{*}{ Total } & \multirow{3}{*}{$\begin{array}{c}\mathrm{p}- \\
\text { Value }\end{array}$} \\
\hline & \multicolumn{2}{|c|}{$\begin{array}{c}\text { Kurang } \\
\text { Baik }\end{array}$} & \multicolumn{2}{|c|}{ Baik } & & \\
\hline & $\mathrm{n}$ & $\%$ & $\mathrm{n}$ & $\%$ & $\mathrm{n}$ & \\
\hline $\begin{array}{c}\text { Kurang } \\
\text { baik }\end{array}$ & 17 & 85,0 & 3 & 15,0 & $\begin{array}{l}2 \\
0\end{array}$ & 0.000 \\
\hline Baik & 5 & 21,7 & 18 & 78,3 & 2 & \\
\hline Jumlah & 22 & & 21 & & 43 & \\
\hline
\end{tabular}

Hasil analisis hubungan antara peran petugas dengan perilaku remaja menunjukkan remaja yang mendapatkan pelayanan dari petugas kesehatan dan perilaku baik yaitu sebanyak 18 orang responden $(78,3 \%)$, sedangkan pada remaja yang tidak mendapatkan pelayanan dari petugas kesehatan dan memiliki perilaku kurang baik sebanyak 5 orang responden $(21,7 \%)$. Dari hasil analisis bivariat chisquare antar kategori pada masing-masing variabel diperoleh nilai $p$ value adalah 0.000 artinya $p$ value $<0.05$, maka mampu membuktikan bahwa adanya hubungan yang signifikan antara peran petugas dengan perilaku remaja dengan nilai $O d d s$ Ratio $(O R)$ adalah sebesar 20,40.

\section{Tabel 7. Distribusi Hubungan Dukungan Keluarga terhadap Perilaku Remaja ke Posyandudi Wilayah KerjaPuskesmas Muara Bulian}

Hasil analisis hubungan antara dukungan keluarga dengan perilaku remaja menunjukkan remaja yang mendapatkan

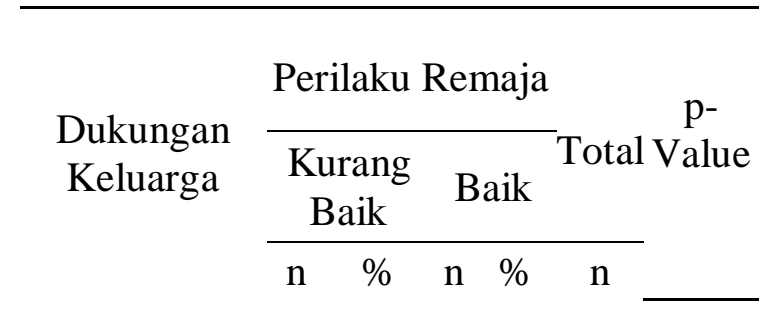

Kurang Baik $14 \quad 87,5 \quad 2$ 12,516

0.001

Baik $\quad 8 \quad 29,6 \quad 1970,4 \quad 27$

Jumlah $\quad 22 \quad 21 \quad 43$

dukungan keluarga dan perilaku baik yaitu sebanyak 19 orang responden (70,4\%), sedangkan pada remaja yang mendapatkan dukungan keluarga dan memiliki perilaku kurang baik sebanyak 8 orang responden $(29,6 \%)$. Dari hasil analisis bivariat chisquare antar kategori pada masing-masing variabel diperoleh nilai $p$ value adalah 0.000 artinya $p$ value $<0.05$, maka mampu membuktikan bahwa adanya hubungan yang signifikan antara dukungan keluarga dengan perilaku remaja dengan nilai $O d d s$ Ratio (OR) adalah sebesar 16,625 berarti remaja yang tidak mendapatkan dukungan keluarga berpeluang perilaku baik sebanyak 16 kali lebih besar untuk ke posyandu dibandingkan dengan remaja yang mendapatkan dukungan keluarga.

\section{Pembahasan}

Distribusi Gambaran Faktor-Faktor yang Mempengaruhi Perilaku Remaja ke Posyandu di Wilayah Kerja Puskesmas Muara Bulian Tahun 2020.

Berdasarkan hasil yang dilakukan dari 43 remaja yang diteliti. Sebagian besarrespondenmemilikiperilakukurangbaik dansebagian kecil memiliki perilaku baik. Hasil penelitian ini sesuai dengan penelitian Nursalam (2014), yang menyatakan kesehatan seseorangatau masyarakat dipengaruhi oleh dua faktorpokok yaitu faktorperilaku (behaviorcauses) dan faktor diluar perilaku (nonbehaviorcauses). Sementara faktor perilaku(behavior causes) dipengaruhi oleh tigafaktor yakni: faktor predisposisi(Predisposing Factors) yang 
meliputi umur,pekerjaan, pendidikan, pengetahuan dansikap, faktor pemungkin (Enabling Factors)yang terwujud dalam lingkungan fisik danjarak ke fasilitas kesehatan, dan faktorpenguat (Reinforcing Factors) yangterwujud dalam dukungan yang diberikanoleh keluarga maupun tokoh masyarakat.

\section{Hubungan Antara Pengetahuan dengan Perilaku Remaja ke Posyandu di Wilayah Kerja Puskesmas Muara Bulian}

Hasil penelitian ini sejalan dengan hasil penelitian oleh Darmawan (2017), Hasil uji statistik diperoleh nilai $\mathrm{p}=0,001$ artinya terdapat hubungan antara pengetahuan dengan kunjungan remaja dalam kegiatan posyandu ( $\mathrm{p}<0,05)$.

\section{Hubungan Antara Sikap dengan Perilaku Remaja ke Posyandu di Wilayah Kerja Puskesmas Muara Bulian}

Hasil penelitian ini sejalan dengan penelitian yag dilakukan oleh pada Nofianti(2012). Hasil dari uji statistik diperoleh nilai $\mathrm{p}=0,009$ yang berarti ada hubungan antara sikap remaja terhadap kegiatan posyandu $(\mathrm{p}<0,05)$.

Remaja yang memiliki sikap positif tetapi perilaku kurang, hal ini karena kurangnya keinginan dari diri remaja sendiri untuk ke posyandu, sehingga walaupun sikap remaja positif, perilaku ibu masih kurang. Terdapat remaja yang memiliki sikap negatif tetapi perilaku baik karena adanya dorongan dan motivasi dari keluarga dan petugas kesehatan untuk ke posyandu. Sebagaimana pendapat Azwar yang menyatakan bahwa pembentukan sikap seseorang banyak dipengaruhi oleh banyak faktor baik yang bersifat intrinsik maupun ekstrinsik orang tersebut. Faktor tersebut biasa berupa pengalaman pribadi, pengaruh orang lain, kebudayaan, media informasi dan faktor emosional orang itu sendiri. Peneliti berasumsi bahwa seseorang yang memiliki sikap baik dalam pemanfaatan pelayanan posyandu lebih besar daripada orang yang berpengetahuan kurang, Hasil penelitian ini membuktikan bahwa teori, dan penelitian orang lain semuanya sesuai dan tidak ada kesenjangan antara hasil, teori, dan penelitian orang lain.

Hubungan Antara Jarak Posyandu dengan Perilaku Remaja ke Posyandu di Wilayah Kerja Puskesmas Muara Bulian

Hasil dari penelitian ini sesuai dengan teori yang menjelaskan bahwa pada umumya seseorang akan mencari tempat pelayanan ke fasilitas kesehatan yang berlokasi dekat dengan tempat tinggal mereka (Suryaningsih, 2012 : 81).Hasil penelitian ini tidak sejalan dengan hasil penelitian Hairunida (2012).Hasil dari uji statistik diperoleh nilai $\mathrm{p}=0,055$ yang berarti tidak ada hubungan antara sikap remaja terhadap kegiatan posyandu ( $\mathrm{p}<$ $0,05)$.

Hubungan Antara Sumber Informasi dengan Perilaku Remaja ke Posyandu di Wilayah Kerja Puskesmas Muara Bulian

Hasil analisis hubungan antara sumber informasi dengan perilaku remaja menunjukkan remaja yang mendapatkan sumber informasi serta perilaku baik yaitu sebanyak 18 orang responden (72\%), sedangkan pada remaja yang mendapatkan sumber informasi dan memiliki perilaku kurang baik sebanyak 7orang responden (28\%). Dari hasil analisis bivariat chisquare antar kategori pada masing-masing variabel diperoleh nilai $p$ value adalah 0.001 artinya $p$ value $<\alpha 0.05$, maka mampu membuktikan bahwa adanya hubungan yang signifikan antara sumber informasi dengan perilaku remaja dengan nilai Odds Ratio (OR) adalah sebesar 12,857 berarti remaja yang tidak mendapatkan sumber informasi berpeluang perilaku baik sebanyak 12 kali lebih besar untuk ke puskesmas dibandingkan dengan remaja yang mendapatkan sumber informasi.Hasil penelitian ini sesuai dengan teori yang menyatakan bahwa Sumber informasi 
adalah segala sesuatu yang menjadi perantara dalam menyampaikan informasi, media informasi untuk komunikasi massa. Sumber informasi dapat diperoleh melalui media cetak (surat kabar, majalah), media elektronik (handphone,televisi, radio, internet), dan melalui kegiatan tenaga kesehatan seperti pelatihan yang di adakan (Notoatmodjo, 2014). Penelitian ini tidak sejalan dengan penelitian yang dilakukan Darmawan (2017)i. Hasil dari uji statistik diperoleh nilai $\mathrm{p}=0,001$ yang berarti ada hubungan antara sumber informasi terhadap kegiatan posyandu $(\mathrm{p}<0,05)$.

Hubungan Antara Peran Petugas dengan Perilaku Remaja ke Posyandu di Wilayah Kerja Puskesmas Muara Bulian Tahun 2020

Dilihat dari peran petugas kesehatan, kejadian kehamilanremaja lebih banyak pada remaja yang menilaiperan petugas kesehatan kurang $(69,4 \%)$. Didapat kanhubungan peran petugas dengan kehamilan remaja. Nurjanah (2017) dalam penelitiannya menunjukkan bahwa informasi yang didapatkan dari petugas kesehatan dapat menekan kejadian pernikahan usia muda dan mencegah kehamilan usia muda.Melalui penelitiannya Pazol (2011) membuktikan bahwa empat hal potensial dalam mencegah kehamilan usia remaja adalah pendidikan seks,komunikasi dengan orangtua, penggunaan kontrasepsi,dan penerimaan layanan kesehatan reproduksi. Peran petugas kesehatan sangat dibutuhkan untuk mengurangi risiko yang terjadi pada kehamilan usia remaja.

Hubungan Antara Dukungan Keluarga dengan Perilaku Remaja ke Posyandu di Wilayah Kerja Puskesmas Muara Bulian Tahun 2020

Hasil penelitian ini sesuai dengan teori yang menyatakan bahwa sesuai dengan teori yang dijelaskan oleh Wetle (1997) dalam Lestari (2011) bahwa keberadaan anggota keluarga dan dukungan yang diberikan memiliki peranan penting dalam mencegah ataumenunda seseorang yang menderita penyakit kronis untuk pergi berobat. Selain itu, dukungan yang diberikan dapat berupa dukungan emosional, dukungan penghargaan, informasional dan instrumental yang mampu mempengaruhi minat seseorang dalam berperilaku (Friedman, 2010).Hasil penelitian ini sejalan dengan penelitian Cahyati (2014) didapatkan nilai $\mathrm{p}=0,0001$ yang berarti ada hubungan antara dukungan keluarga dengan pemanfaatan pelayanan posyandu ( $\mathrm{p}$ value < 0,05). Hasil dari penelitian ini juga sesuai dengan teori yang dijelaskan oleh Wetle(1997) dalam Lestari (2011) bahwa keberadaan anggota keluarga dan dukungan yang diberikan memiliki peranan penting dalam mencegah atau menunda seseorang yang menderita penyakit kronis untuk pergi berobat.Selain itu, dukungan yang diberikan dapat berupa dukungan emosional, dukungan penghargaan, informasional dan instrumental yang mampu mempengaruhi minat seseorang dalam berperilaku (Friedman, 2010).

\section{SIMPULAN}

Berdasarkan hasil penelitian dan pembahasan yang telah di jabarkan pada bab sebelumnya, maka kesimpulan yang dapat ditarik dalam penelitian ini adalah Mayoritas perilaku remaja kurang baik dalam melakukan kunjungan keposyandu di wilayah kerja Puskesmas Muara Bulian, Adahubungan yang bermakna antara pengetahuan, sikap, jarak posyandu, sumber informasi, peran petugas, dan dukungan keluarga dengan perilaku remaja keposyandu di wilayah kerja Puskesmas Muara Bulian tahun 2020.

\section{SARAN}

Diharapkan kepada pihak Puskesmas Muara Bulian perlu peran aktif tenaga kesehatan dalam memberikan penyuluhan dan mensosialisasikan posyandu remaja. Sasaran penyuluhan tidakhanya remaja, tetapi juga pihak 
keluarga. Puskesmas diharapkan melengkapi sarana dan prasarana untuk menunjang kegiatan pelayanan kesehatan padaremaja seperti pemberian penyuluhan dan masukan bagi remaja dengan menggunakan leaflet, lembar balik serta video agar tidak membosankan dan tenaga kesehatan berperan aktif dalam pelaksanaan PKPR ke sekolah.

\section{DAFTAR PUSTAKA}

Ahyani, Latifah Nur dan Astuti, Dwi. 2018 Psikologi Perkembangan Anak Dan Remaja. Penerbit Universitas Muria, Kudus.

Apritia,Mia, dkk. 2019

Peran Posyandu Remaja Terhadap Perilaku Kesehatan Reproduksi Remaja Di Kota Tanjung Pinang.Jurnal Dinkes Kota Tanjung Pinang

Badan Pusat Statistik Kabupaten Batang Hari, 2018

Kabupaten Batang Hari Dalam Angka. Batang Hari: xlix + 408 hlm.

Darmawan, Kompiang Ngurah. 2015

Faktor-Faktor Yang Mempengaruhi Perilaku Kunjungan Masyarakat Terhadap Pemanfaatan Pelayanan Posyandu Di Desa Pemecutan Kelod Kecamatan Denpasar Barat. Jurnal STIKES Bina Husada.

Jamiatun Hasanah,Indah. 2015

Faktor-Faktor Yang Berhubungan Dengan Perilaku Ibu Balita Dalam Menimbang Anaknya Ke Posyandu Di Wilayah Kerja Puskesmas Kelurahan Rorotan Kecamatan Cilincing Jakarta Utara.

Kemenkes RI. 2011

Modul Pelatihan Pelayanan Kesehatan Peduli Remaja. Jakarta : vii +193 hlm. . 2018

Petunjuk Teknis Penyelenggaraan Posyandu Remaja. Penerbit Kemenkes RI. Jakarta: xi+116 hlm. 2018
Profil Kesehatan Indonesi. Penerbit Kemenkes RI. Jakarta: xxxix $+311 \mathrm{hlm}$. 2018

Manajemen Terpadu Pelayanan Kesehatan Remaja Di Fasilitas Kesehatan Tingkat Pertama. Penerbit Kemenkes RI. Jakarta: 209 hlm. 2019

Petunjuk Teknis Penyelenggaraan Posyandu Remaja. Penerbit Kemenkes RI, Jakarta: ix+248 hlm. Mahmudah, dkk. 2016

Faktor-faktor yang berhubungan dengan perilaku seksual remaja di kota Padang. http://jurnal.

Fk.unand.ac.id

Notoadmodjo, Soekidjo. 2014.

Ilmu Perilaku Kesehatan. Penerbit Rineka Cipta. Jakarta : ix + 174 hlm 2018

Metodologi Penelitian Kesehatan. Penerbit Rineka Cipta. Jakarta : xix + $243 \mathrm{hlm}$. 2018

Promosi Kesehatan Dan Perilaku Kesehatan. Penerbit Rineka Cipta. Jakarta : ix + 174 hlm.

Rusmiati, desi, 2017

Metodologi penelitian dan biostatistik untuk mahasiswa kebidanan. Penerbit Raja Grafindo Persada, Jakarta :x + 214 hlm.

Saripah,Ipah. 2018

Permasalahan Anak Dan Remaja Serta Solusinya. Penerbit Alfa Beta, Bandung : viii + 156 hlm.

Sarwono,SarlitoWirawan. 2018

Psikologi Remaja. Penerbit Raja

Grafindo Persada, Depok : xxii +322 hlm.

Wawan dan Dewi.2019

Teori Dan Pengukuran

Pengetahuan, Sikap, Dan Perilaku

Manusia. Penerbit Nuha Medika.

Yogyakarta : vii + 94 hlm. 